\title{
Using Nematode Community to Evaluate Banana Soil Food Web in Mekargalih, Cianjur, West Java
}

\author{
Dale Akbar Yogaswara*, Hikmat Kasmara and Wawan Hermawan \\ Department of Biology, Faculty of Mathematics and Natural Sciences, Universitas Padjadjaran, \\ Jl. Raya Bandung Sumedang KM. 21, Jatinangor, Sumedang Regency, West Java, Indonesia
}

\begin{abstract}
Soil biota is very diverse and contributes widely to ecosystem services that are important in the sustainable function of natural and managed ecosystems. Knowing the condition of the soil food web through the communities that inhabit it is necessary to assess the productivity of the soil. Nematode communities in the soil food web can be used as indicators because of their high abundance, and they inhabit various trophic levels, and participate in several important processes in the soil. The soil food web condition from three locations (Agr1, Agr2, Agr3) through the nematode functional index was evaluated using the maturity index (MI), the maturity index 2-5 (MI-25), the plant-parasitic index (PPI), the channel index (CI), the enrichment index (EI), the structure index (SI), and the basal index (BI). Nematode diversity was evaluated using Simpson's index of diversity, dominance, and evenness. The MI and MI2-5 scores indicated that Agr3 (3.81) had an undisturbed food web, while Agr2 (2.88 and 3.0) and Agr1 (2.5 and 2.51) were in a moderate condition with minor disturbances. Fauna profile analysis using SI and EI shows that Agr3 and Agr1 had an undisturbed soil food web, and Agr2 was in enriched conditions. CI results found that Agr1 and Agr3 had a fungal decomposition pathway while Agr2

ARTICLE INFO

Article history:

Received: 30 October 2020

Accepted: 29 March 2021

Published: 28 May 2021

DOI: https://doi.org/10.47836/pjtas.44.2.12 had a bacterial decomposition pathway. This research showed that prospect of the nematode community to serve as a collection of biological indicator data in assessing soil or ecosystem health can be considered in further research.
\end{abstract}

E-mail addresses:

dale.akbar@gmail.com (Dale Akbar Yogaswara)

hikmat@unpad.ac.id (Hikmat Kasmara)

wawan.hermawan@unpad.ac.id (Wawan Hermawan)

*Corresponding author
Keywords: Agriculture, banana, food web, nematode 


\section{INTRODUCTION}

Soil is the foundation of terrestrial ecosystems, where the majority of the ecosystem services humans need come from. These ecosystem services are inherently dependent on soil health and the diversity of soil food web biota. They play a role in nutrient cycling, mineralization, and decomposition. The agricultural practice affects the soil food web structure and services providing by the soil (de Vries et al., 2013). Banana is one of the leading fruit commodities in West Java and contributes about $15.5 \%$ of national production (Statistics Indonesia [BPS], 2019). In West Java, Cianjur Regency is the largest banana producer with 1.12 million tons in the last five years (BPS, 2019). It is important to regularly evaluate soil food webs for sustainable crop yields and soil health (Kibblewhite et al., 2008).

Nematodes can be used as indicators of the soil food web because they meet several conditions as a good indicator: large abundance, varying trophic levels, and diverse life strategies (Brussaard et al., 2004). Nematodes also have several advantages as indicators: nematodes have a short generation period that allows them to respond quickly to food availability and environmental disturbance (Bongers, 1990; Wasilewska, 1989). Nematodes trophic levels are also useful for determining ecosystem function, and they are easily identified and low in cost (Neher et al., 1995). The nematode community structure index also reflects the process of soil succession (Neher \& Campbell, 1994) and can be used as a bioindicator in monitoring the condition of agricultural soils (Bongers \& Ferris, 1999; Wasilewska, 1989; V. R. Ferris \& Ferris, 1974).

To assess soil food webs through the nematode community several indexes developed using the colonizer-persister scale (c-p scale), such as the maturity index (MI) for free-living nematodes and the plant-parasitic index (PPI) for herbivorous nematodes (Bongers, 1990). The nematode community can be used to analyze food web conditions and describe ecosystem succession levels based on groups of nematode feeding habits. Nematode communities were accessed using an ecosystem functional index consisting of enrichment index (EI), basal index (BI), channel index (CI), and structural index (SI) (H. Ferris et al., 2001). Nematodes have the potential as bioindicators for assessing disturbance from banana system practices and evaluating soil health.

Research on nematodes to evaluate soil and environmental health in Indonesia is still limited. Nematode studies in Indonesia focus on plant-parasitic nematodes (Budiman et al., 2020; Djiwanti, 2019; Handayani et al., 2020; Kurniawati et al., 2020; Lisnawita et al., 2012; Mirsam et al., 2020; Mutala'liah et al., 2018), parasites in vertebrates (Ahmad \& Tiffarent, 2020; Baihaqi et al., 2019; Khoirani et al., 2020; Sakaguchi et al., 2019), and nematode ecology (Krashevska et al., 2019). Therefore, this research needs to be carried out considering the great benefits and advantages of nematodes as bioindicators and the limited research on 
nematode ecology in Indonesia. This study aimed to evaluate banana soil food webs using nematode communities.

\section{MATERIALS AND METHODS}

\section{Experimental Design}

The experimental design in this study is quantitative observation. The nematode functional index was used to analyze community data taken from three locations (Agr1, Agr2, and Agr3). The results of the analysis were described according to the interpretation of each index and did not use any statistical analysis.

\section{Site Description}

Soil sampling was in Mekargalih Village, Cianjur Regency, West Java, Indonesia because it is the largest banana producer in West Java (BPS, 2019). Three banana systems were used for soil sampling with all location coordinates recorded using the
Global Positioning System (GPS) from Google Maps and converted to sexagesimal using Microsoft Excel. Agr2 (6 $6^{\circ} 1^{\prime} 37^{\prime}$ ' S, $\left.107^{\circ} 12^{\prime} 5^{\prime \prime} \mathrm{E}\right)$ is the largest banana system with $481 \mathrm{~m}^{2}$, the second largest is Agr3 (6 $6^{\circ} 1^{\prime} 31^{\prime \prime} \mathrm{S}, 107^{\circ} 12^{\prime} 9$ ' $\mathrm{E}$ ) with $433 \mathrm{~m}^{2}$, and the smallest is Agr1 (6 $6^{\circ} 41^{\prime} 34^{\prime \prime} \mathrm{S}, 107^{\circ} 12^{\prime} 6^{\prime \prime}$ E) with $412 \mathrm{~m}^{2}$. Soils from all locations have similar physicochemical properties: high humidity, clay type, dark brown color, acidic, moderate-to-high soil organic carbon (SOC), and high cation exchange capacity (CEC) (Table 1).

Banana plants at each location had different ages; two months in Agr1, 15 months in Agr2, and 14 months in Agr3. At the beginning of planting, soil preparation was given, such as manure application, lime application, fungicide, and ridge tillage with soil hoeing. Agr1 and Agr2 had no other vegetation besides banana plants, while Agr3 was full of weeds.

Table 1

Soil physicochemical properties of all locations

\begin{tabular}{|c|c|c|c|c|c|c|c|c|c|}
\hline & $\begin{array}{l}\text { Moisture } \\
(\%)\end{array}$ & $\begin{array}{l}\text { Sand } \\
(\%)\end{array}$ & $\begin{array}{l}\text { Silt } \\
(\%)\end{array}$ & $\begin{array}{l}\text { Clay } \\
(\%)\end{array}$ & Texture & Color & $\begin{array}{l}\mathrm{pH} \\
\left(\mathrm{H}_{2} \mathrm{O}\right)\end{array}$ & $\begin{array}{l}\text { SOC } \\
(\%)\end{array}$ & $\begin{array}{l}\text { CEC } \\
(\mathrm{cmol}(+) / \\
\mathrm{kg})\end{array}$ \\
\hline Agr1 & 78 & 7 & 26 & 67 & Clay & $\begin{array}{l}\text { Dark } \\
\text { brown }\end{array}$ & 5.57 & 1.50 & 33.98 \\
\hline Agr2 & 70 & 6 & 40 & 54 & $\begin{array}{l}\text { Silty } \\
\text { clay }\end{array}$ & $\begin{array}{l}\text { Dark } \\
\text { brown }\end{array}$ & 5.48 & 2.45 & 33.98 \\
\hline Agr3 & 70 & 5 & 27 & 68 & Clay & $\begin{array}{l}\text { Dark } \\
\text { brown }\end{array}$ & 5.57 & 1.77 & 38.02 \\
\hline
\end{tabular}

Note $. \mathrm{SOC}=$ Soil organic carbon $; \mathrm{CEC}=$ Cation exchange capacity 


\section{Soil Sampling and Nematodes}

Identification. A total of 3 composite samples were taken in January 2020 from 3 locations (Agr1, Agr2, and Agr3). Each composite sample consisted of $10 \mathrm{sub}$ samples taken using a zig-zag pattern along the transect (Coyne et al., 2014). There were 10 sub-samples taken because the land area is less than $500 \mathrm{~m}^{2}$ (Celleti \& Potter, 2016). Sub-samples were taken at 15-20 cm depths (Hooper et al., 2005) using soil augers (4 cm diameter) (Van Bezooijen, 2006) and stirred to become composite samples (Hooper et al., 2005). Samples were placed in labeled plastic bags and transported to the laboratory in a cooler box. Nematodes were isolated from $100 \mathrm{~g}$ of soil using a modified Baermann funnel method (Van Bezooijen, 2006). Nematodes were transferred to the top of the slide using a micropipette and observed using high magnification under a microscope (Nikon ECLIPSE E100LED MV R).

Nematodes were identified based on morphological characteristics (e.g. stoma shape, feeding apparatus, pharyngeal shape, genital branch, and tail shape) down to the family level using several keys for nematode identification. Order of Rhabditida: Andrássy (1983); Nguyen (2006, 2009); Scholze and Sudhaus (2011). Order of Dorylaimida: Jairajpuri and Ahmad (1992); Peña-Santiago (2006, 2014a); Vinciguerra (2006). Order of Mononchida: Peña-Santiago (2014b); Zulini and Peneva (2006). Order of Tylenchida: Siddiqi (2000); Subbotin (2014).

\section{Nematodes Community Analyses}

Nematodes were identified to the family level because they have the same anatomical and physiological attributes and feeding habits that are useful for fauna analysis $(\mathrm{H}$. Ferris et al., 2001). The diversity index of the nematode community at each location was calculated using Simpson's index of diversity, dominance, and evenness. Simpson (1949) gives a formula for dominance and diversity index as:

$$
\begin{aligned}
& \lambda=\sum \frac{n_{i}\left[n_{i}-1\right]}{N[N-1]} \\
& \mathrm{D}=1-\lambda
\end{aligned}
$$

Pielou (1969) provide a formula for the evenness index derived from Simpson's dominance as:

$$
\mathrm{E}=\sum_{i=1}^{n} \frac{v_{i} \cdot f_{i}}{N}
$$

where $\lambda$ is Simpson's dominance, $D$ is Simpson's diversity, $\mathrm{n}_{\mathrm{i}}$ is the number of individuals in family $i, \mathrm{~N}$ is the total individuals in the community, and $\mathrm{S}$ is the number of families in the community. Interpretation refers to the guidelines for interpreting the Simpson diversity index scores by Guajardo (2015) (Table 2).

The nematode family is classified into functional groups and colonizer-persister scales (c-p). Colonizer-persister (c-p) is a scale assigned from 1-5 to the nematode family based on $r$ and $K$ characteristics $(H$. Ferris et al., 2001). The characteristics of the $r$ are tolerant to disturbance, as decomposers, high metabolic activity, high fecundity, and a short life cycle. $\mathrm{K}$ group is sensitive and 
Table 2

Guidelines for interpreting Simpson diversity index scores

\begin{tabular}{ll}
\hline Simpson score & Interpretation \\
\hline 0.0 & Absence of diversity (homogeneity) \\
$0.01-0.4$ & A low degree of diversity/heterogeneity \\
$0.41-0.60$ & A moderate degree of diversity/heterogeneity \\
$0.61-0.80$ & A moderately high degree of diversity/heterogeneity \\
$0.81-0.99$ & A high degree of diversity/heterogeneity \\
1.0 & Absolute (perfect) diversity/heterogeneity \\
\hline
\end{tabular}

tends to be in undisturbed conditions, large nematodes, long life cycle, low fecundity, and consists of carnivores and omnivores (Bongers, 1990; H. Ferris \& Bongers, 2006; H. Ferris et al., 2001).

The weighted average of nematode communities was calculated using the c-p scale for each family or the so-called maturity index (MI) and plant parasite index (PPI) (H. Ferris et al., 2001). MI scores varied from 1 in the highly enriched state to 5 in the undisturbed condition. H. Ferris et al. (2001) provide a general formula for calculating the index in MI families as:

$$
\mathrm{XI}=\sum_{i=1}^{n} \frac{v_{i} \cdot f_{i}}{N}
$$

where XI is the index of interest (MI for free-living and PPI for plant-parasitic nematode), $\mathrm{v}_{i}$ is the colonizer-persister (c-p) value assigned to taxon $i$, and $\mathrm{f}_{i}$ is the number of nematodes in each of the $f$ taxa that meet the criteria of the index. Interpretation of MI values based on the classification is given by Moreno et al. (2011).

Analysis of soil food webs has been measured based on the presence and abundance of nematode functional groups (feeding habits or trophic level). The determination of the functional groups refers to the description by Yeates et al. (1993), based on the principle that the presence and abundance of functional groups in an ecosystem is a consequence of environmental change (H. Ferris et al., 2001). H. Ferris et al. (2001) then classified the food web into 3 conditions: $b$ (basal), $e$ (enriched), and $s$ (structured), and in their application they are expressed as the value of the fauna component $(b, e$, and $s) . b$ is the value of the basal group $\left(\mathrm{Ba}_{2}\right.$ and $\left.\mathrm{Fu}_{2}\right)$ in the community, and it can be calculated as:

$$
b=\left(\mathrm{Ba}_{2}+\mathrm{Fu}_{2}\right) \cdot \mathrm{W}_{2}
$$

$\mathrm{Ba}_{2}$ is a group of bacterivore c-p2 and $\mathrm{Fu}_{2}$ is a group of c-p2 fungivore nematodes. $e$ is the value of the opportunist nematode group $\left(\mathrm{Ba}_{1}\right.$ and $\left.\mathrm{Fu}_{2}\right)$ in the community, so it can be expressed in:

$$
e=\left(\mathrm{Ba}_{1} \cdot \mathrm{W}_{1}\right)+\left(\mathrm{Fu}_{2}+\mathrm{W}_{2}\right)
$$

$\mathrm{Ba}_{1}$ is the number of individuals of the bacterivore $\mathrm{c}-\mathrm{p} 1$ group and $\mathrm{Fu}_{2}$ is the number of individuals of the fungivore c-p2 group. $s$ is the value of all functional 
groups present in the community, and it can be calculated as:

$$
\begin{aligned}
& s=\left(\mathrm{Ba}_{\mathrm{n}} \cdot \mathrm{W}_{\mathrm{n}}\right)+\left(\mathrm{Fu}_{\mathrm{n}} \cdot \mathrm{W}_{\mathrm{n}}\right)+\left(\mathrm{Ca}_{\mathrm{n}} \cdot \mathrm{W}_{\mathrm{n}}\right) \\
& +\left(\mathrm{Om}_{\mathrm{n}} \cdot \mathrm{W}_{\mathrm{n}}\right)
\end{aligned}
$$

In $s$, all the c-p of bacterivores $\left(\mathrm{Ba}_{\mathrm{n}}\right)$, all the c-p of fungivores $\left(\mathrm{Fu}_{\mathrm{n}}\right)$, all the c-p of carnivore $\left(\mathrm{Ca}_{\mathrm{n}}\right)$, and all the c-p of omnivore $\left(\mathrm{Ca}_{\mathrm{n}}\right)$ in the community were counted. $\mathrm{W}_{\mathrm{n}}$ is the weight or constant of the functional group W at c-p $n, H$. Ferris et al. (2001) assigned weights as follows: 3.2 for $\mathrm{W}_{1}$; 0.8 for $\mathrm{W}_{2} ; 1.8$ for $\mathrm{W}_{3} ; 3.2$ for $\mathrm{W}_{4} ; 5$ for $\mathrm{W}_{5}$ (Figure 1).

Based on the food web classification, $\mathrm{H}$. Ferris et al. (2001) formulated the ecosystem functional index. This index consists of the structure index (SI), the enrichment index (EI), the basal index (BI), and the channel index (CI). SI provides information on the complexity of nematode interactions between levels in the food web. SI can be stated in:

$$
\mathrm{SI}=\frac{s}{s+b} \cdot 100
$$

Since all nematode functional groups in the community were included in the calculation, the SI values can be used as an indicator of a good soil food web (scale 0 degraded - 100 highly structured). EI provides information regarding the activities of opportunist groups $\left(\mathrm{Ba}_{1}\right.$ and $\left.\mathrm{Fu}_{2}\right)$ that react to the availability of food sources in the soil, so that it can be expressed in:

$$
\mathrm{EI}=\frac{e}{e+b} \cdot 100
$$

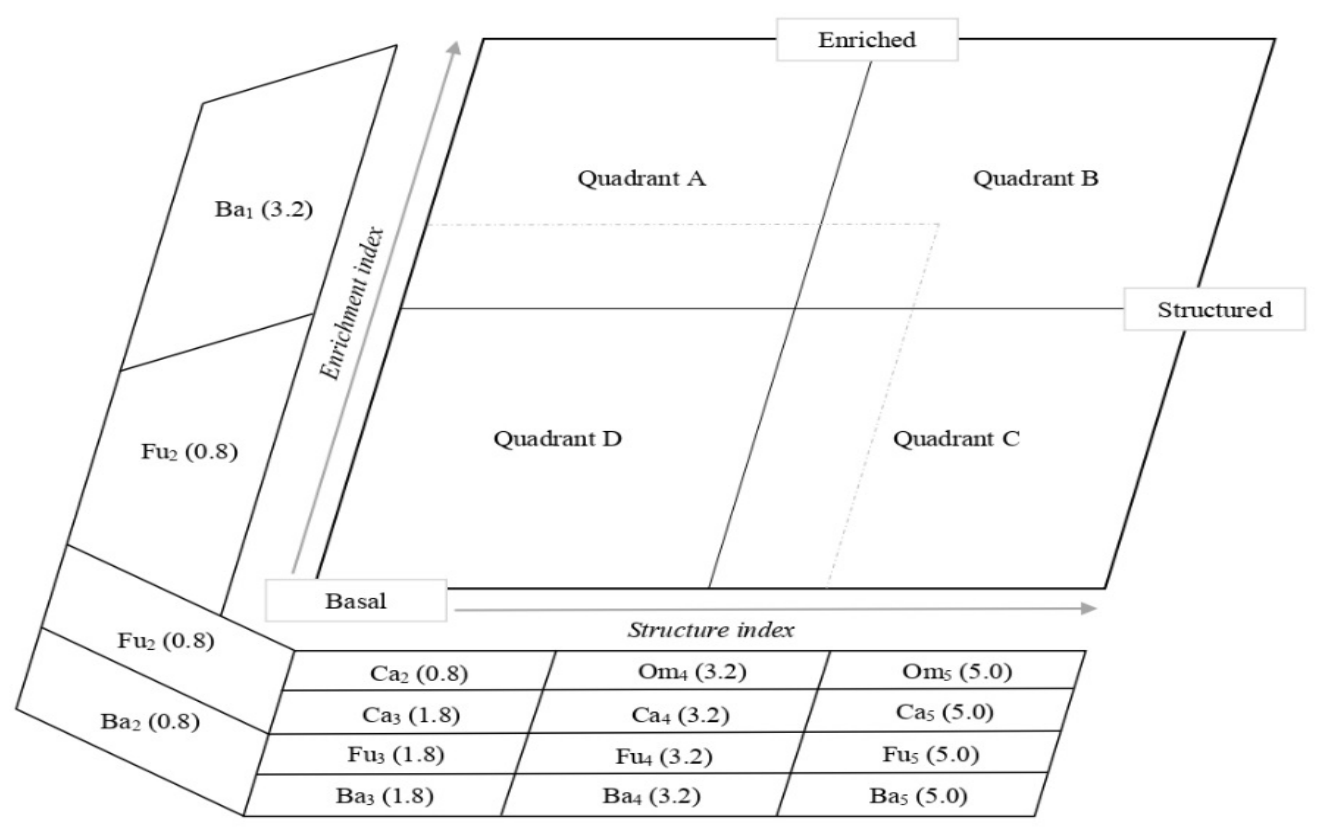

Figure 1. Fauna profile analysis of soil food webs. Divide the food web conditions into 4 quadrants and 3 criterias. It also shows the weight of each c-p of the nematode functional group (H. Ferris et al., 2001) 
The EI value can be used to evaluate the availability of resources in the food web. A high EI can indicate that the soil is being enriched (e.g. manure application, the addition of plant litter, or natural disaster). The EI value is on a scale of $0-100$ where 0 indicates a depleted resource and is 100 heavy enrichment. BI is an indicator of the level of disturbance in the soil food web, so that it can be expressed in:

$$
\mathrm{BI}=\frac{b}{e+s+b} \cdot 100
$$

On a scale of $0-100$ on BI, a value of 0 indicates a highly degraded soil food web and a value of 100 indicates an undisturbed soil food web. CI is calculated as the proportion of fungal-feeding nematodes compared to enrichment-opportunistic bacterial-feeders nematodes. It provides information regarding the decomposer pathway in the soil food web and can be expressed in:

$$
\mathrm{CI}=\frac{F u_{2} \cdot W_{2}}{B a_{1} \cdot W_{1}+F u_{2} \cdot W_{2}} \cdot 100
$$

If the CI value $<50$ that indicates the soil food web has a bacterial decomposition pathway, if the CI value $>50$ indicates that the soil food web has a fungal decomposition pathway, and the CI value of 50 indicates that the soil food web has a balanced decomposition pathway, where $\mathrm{Ba}, \mathrm{Fu}, \mathrm{Ca}$, and $\mathrm{Om}$ are the abundance of bacterivorous, fungivorous, carnivorous, and omnivorous nematodes; $n$ is the $c-p$ value for the nematode families; $\mathrm{W}$ is the weight of each c-p of functional group: c-p1 3.2; c-p2 0.8; c-p3 1.8; c-p4 3.2; c-p5 5 (Figure 1).

Its use to interpret food web conditions, the ecosystem functional index is not only used as a single standing index. Berkelmans et al. (2003) combined SI and BI to describe the effects of agricultural land management on soil food webs through nematode communities. Then H. Ferris et al. (2001) developed a fauna profile analysis based on a combination of SI and EI, which was transformed into a Cartesian diagram and divided into four quadrants and three conditions (Figure 1). Each quadrant represents different food web conditions.

\section{RESULTS AND DISCUSSION}

\section{Diversity of the Nematode Families}

Fifteen families of nematodes were identified and classified into their functional groups (Table 3): five bacterivores, one fungivore, four herbivores, three omnivores, and two carnivores. From the diversity index, the communities in Agr1 have high diversity, while Agr2 and Agr3 in moderate. Richness (Hill's $\mathrm{H}_{0}$ ) and evenness (Jost, 2010) affect the diversity index value. Agr1 has the highest diversity because it is richer and has a more even distribution of abundance. Two families dominate the Agr2 community (Hoplolaimidae and Meloidogynidae) and three families dominate the Agr3 (Hoplolaimidae, Heteroderidae, and Meloidogynidae). The low dominance index value indicates that there are no taxa that dominate the abundance and on the even distribution in a community. 
Table 3

Abundance of nematode functional groups in each location

\begin{tabular}{lccccc}
\hline \multirow{2}{*}{ Family } & c-p & \multicolumn{3}{c}{ Abundance } & Functional groups \\
\cline { 3 - 5 } & & Agr1 & Agr2 & Agr3 & \\
\hline Rhabditidae & 1 & 1 & 1 & - & Bacterivorous \\
Cephalobidae & 2 & 50 & 5 & 1 & Bacterivorous \\
Rhabditonematidae & 2 & 9 & - & 1 & Bacterivorous \\
Ostellidae & 2 & 1 & - & - & Bacterivorous \\
Aphelenchidae & 3 & 14 & 3 & 1 & Fungivorous \\
Teratocephalidae & 3 & 2 & - & - & Bacterivorous \\
Hoplolaimidae & 3 & 26 & 33 & 52 & Herbivorous \\
Meloidogynidae & 3 & 16 & 26 & 13 & Herbivorous \\
Pratylenchidae & 3 & - & 5 & 4 & Herbivorous \\
Heteroderidae & 3 & - & 7 & 12 & Herbivorous \\
Dorylaimidae & 4 & 9 & 1 & 5 & Omnivorous \\
Nordiidae & 4 & 12 & 5 & 9 & Omnivorous \\
Qudsinematidae & 4 & 2 & 1 & - & Omnivorous \\
Mononchidae & 4 & - & 1 & 2 & Carnivorous \\
Aporcelaimidae & 5 & - & - & 2 & Carnivorous \\
\hline
\end{tabular}

Note. $\mathrm{c}-\mathrm{p}=$ Colonizer-persister

High-dimensional ecological data are summarized using a diversity index for easy understanding and comparison (Daly et al., 2018). The summary may also result in missing some important information from the community. Agr1 has a good diversity index value, but the function of the taxa present is unknown. Therefore, a functional index is needed to describe each taxa function that is present in the community.

\section{Soil Food Web Condition}

All locations are categorized as semiconventional with manure, lime, and fungicides applications, using ridge tillage, no crop rotation, and monoculture. The abundance and diversity of nematodes in semi-conventional farming are smaller than in organic agriculture and natural ecosystems. Besides that, the families present were not much different. Apart from being limited by environmental conditions and soil physicochemical properties, nematode communities are also greatly influenced by the plants growing on the soil (Freckman \& Caswell, 1985).

Manure application increases the abundance and richness of soil nematodes (X. Liu et al., 2020). Manure increased the abundance of nematodes in Agr 1 by $36.46 \%$ 
compared to Agr 2 and $28.67 \%$ against Agr3. The abundance of the opportunist group decreased from day 21 (Ettema \& Bongers, 1993) to 77 (Sholeha et al., 2017) days after manure application due to reduced resources. The meta-analysis conducted by $\mathrm{T}$. Liu et al. (2016) stated that manure increased nematode abundance by $37 \%$.

Ridge tillage is part of conventional tillage (CT) and affects soil nematode communities (Okada \& Harada, 2007). This study shows that Agr1 (CT) has a higher diversity index, evenness index, PPI, and PPI/MI compared to no-tillage (NT) Agr2 and Agr3. CT decreases MI, MI2-5, SI, and increases PPI. The abundance of bacterivores (44.06\%) was higher and lower herbivores (29.37\%) in Agr1 compared to Agr2 (6.81\% and 81.61\%) and Agr3 (1.96\% and $79.41 \%)$. Research from Lenz and Eisenbeis (2000) also shows similar results. Agricultural practices such as CT cause changes in soil physical properties that affect the soil nematode community structure (Wardle, 1995).

This study showed the highest abundance of c-p2 Cephalobidae (Agr1 $34.9 \%$ ) followed by the lowest EI coming from soil treated with fungicides (Agr1). Fungicide treatment was also associated with a decrease in predatory (omnivores and carnivores) and the low abundance of the bacterivore group (Ortiz et al., 2016; Yardim \& Edwards, 1998). Predators on Agr1 (16.78\%) were lower than Agr3 (17.65\%) but higher than Agr2 (9.19\%). The c-p2 abundance of Cephalobidae is hypothesized more affected by enrichment than the fungicide treatment. The nematode community had already recovered from the fungicide due to the small amount applied in the early of the plantation. Fungicides have less impact on the soil community than insecticides and herbicides (Foissner, 1997) and enrichment in the soil is a disturbance that can cause retrogression in the nematode succession process (Neher, 1999).

The lime treatment has no effect on the soil nematode community (Varga et al., 2019) because nematodes are more affected by soil $\mathrm{pH}$. Damage caused by herbivorous nematodes has increased in monoculture agriculture (Quénéhervé et al., 2011). Crop rotation can improve soil quality, such as soil community structure, organic matter, and moisture (Ponge et al., 2013). A longterm crop rotation on banana farming was able to increase MI, SI, EI, diversity index, and led to a highly structured food web reported by Zhong et al. (2015). The fallow effect is also needed to restore the nematode community structure and reduce the herbivorous nematode population (Masse et al., 2002; Wang et al., 2004).

Vegetation type (Cesarz et al., 2013) and soil properties determine the shape of nematode communities as they respond to changes in the environment (Nielsen et al., 2014). Bacterivore and fungivore groups are low in soil with acidic conditions. However, the higher abundance of Agr1 resulted from manure application. Research by Renčo et al. (2020) also got the same result. The abundance of the bacterivore, fungivore, and herbivore groups has a positive correlation with soil moisture. Omnivore and carnivore 
abundance has a negative correlation with soil moisture (Nielsen et al., 2014; Treonis et al., 2019). The abundance of the bacterivore and fungivore groups in Agr1 was higher than Agr2 and Agr3 (Table 3). Meanwhile, the lowest herbivore abundance in Agr1 was due to single vegetation (banana).

Soil organic matter (SOM) content correlated positively with the bacterivore and fungivore groups due to microbial activity (Treonis et al., 2019). Otherwise, Barros et al. (2017) reported that SOM negatively correlated with herbivore groups. However, Agr1 had the highest abundance of bacterivore and fungivore groups. Agr2 and Agr3 with higher SOM content had a very low richness of bacterivores and fungivores. Sandy soil textures are preferred for nematodes and have a greater abundance than clay soils. Larger pores in sand texture are easier for aeration and the spatial distribution of the nematodes (Kim et al., 2017). The c-p scale assessment was applied to the identified nematode families. Based on the criteria of $r$ and $\mathrm{K}$ (H. Ferris et al., 2001), c-p1-2 nematodes are sensitive to enrichment and the most resistant to environmental disturbances. Meanwhile, the sensitive group to environmental disturbances and changes belongs to c-p45 nematodes (Bongers \& Bongers, 1998). This concept makes it possible to determine the disturbance level and the ecosystem succession rate using MI. Increasing MI value indicates succession and decreasing MI value indicates retrogression.

In measuring ecosystem disturbance, Korthals et al. (1996) modified the MI by leaving the c-p1 nematode from the MI calculation (which can cause bias) known as MI2-5. The PPI is used to measure the average weight of family frequencies based on the c-p scale for herbivorous or plantparasitic nematodes. PPI is compared with the MI value which is called the PPI/MI ratio. Enrichment in the soil can cause the ratio value to decrease due to decreasing MI value and vice versa (Bongers \& Korthals, 1995). The evaluation of wellcontrolled herbivore nematode populations by carnivorous and omnivorous nematodes is suggested to use the PPI/MI score.

Result of the MI (Table 4), Agr3 has a high MI score with succession already at the structured level. The structured level had a higher abundance of the c-p45 group (17.65\%) than the c-p1-2 group (2.94\%). Agr2 has a good MI score with succession at the mature level. The good level succession has an abundance of the c-p4-5 group (9.09\%) relatively balanced than the c-p1-2 group (10.23\%). Agr1 has a moderate MI score and succession also at moderate levels. For moderate or lower succession level (disturbed and degraded), the community composition is dominated by the c-p1-2 group (51.75\%) than the c-p4-5 group (16.78\%).

In interpreting the MI score, the cause of the decrease in the MI needs to be known for a more comprehensive understanding. Approximately five-six weeks before the soil sample taken from Agr1 manure is applied. Less than a week after manure application, the abundance of opportunist groups (Ba1 and Fu2) (Bongers \& Bongers, 1998) increased due to high soil microbial activity. After three weeks, basal groups 
Table 4

Diversity and ecological functional index

\begin{tabular}{lccc}
\hline & Agr1 & Agr2 & Agr3 \\
\hline Diversity index & 0.81 & 0.76 & 0.70 \\
Dominance index & 0.19 & 0.24 & 0.30 \\
Evenness index & 0.45 & 0.38 & 0.31 \\
Hill's H $H_{0}$ & 12 & 11 & 11 \\
Maturity index & 2.5 & 2.88 & 3.81 \\
Maturity index 2-5 & 2.51 & 3 & 3.81 \\
Plant-parasitic index & 3 & 3 & 2.95 \\
PPI/MI & 1.2 & 1.04 & 0.77 \\
Structure index & 70.95 & 84.62 & 96.36 \\
Enrichment index & 23.32 & 52.24 & 42.86 \\
Channel index & 77.78 & 42.86 & 100 \\
Basal index & 26.69 & 13.17 & 3.54 \\
\hline
\end{tabular}

(Ba2 and $\mathrm{Fu} 2$ ) such as Cephalobidae (Bongers et al., 1991) replace the population of opportunist groups due to decreased resources of the manure (Ettema \& Bongers, 1993). Thus, the abundance of Cephalobidae on Agr1 was not due to disturbances in the soil food web but a succession process after manure application. The presence of c-p4-5 nematode on Agr1 also indicates that the fungicide was applied in low doses. According to Briar et al. (2012), the omnivore and carnivore c-p4-5 groups did not appear in chemically treated soils before disturbance levels could be reduced or eliminated.

Basal groups (c-p2 Cephalobidae) can survive in disturbed conditions because they can enter the anhydrobiosis stage and dauer larvae if environmental conditions are not favorable. The life cycle resume once the conditions are favorable (McSorley, 2003). MI2-5 is used to measure the level of disturbance based on the c-p scale of families present in the community. From the MI2-5 score, Agr1 and Agr2 are soil food webs with minor disturbances and Agr3 with stable conditions.

The PPI/MI shows that Agr3 has a score of $<1$ (Table 4), while Agr1 and Agr2 have a score $>1$. Based on their role in the ecosystem, the presence of herbivores provides a different interpretation from free-living. A single herbivore individual remains a threat to plant health and crop yields. However, eliminating herbivorous groups is impossible. Thus, the PPI/MI score can be used to assess the risk of herbivore groups towards agriculture. If the score is $<1$, the herbivore population is under control and if the score is $>1$, it is necessary to 
take precautions to reduce the herbivorous nematode population.

Agr1 and Agr3 have a fungal pathway, and Agr 2 has a bacterial pathway but is close to balance. The fungal pathway shows two things: the soil litter is dominated by lignin and cellulose; slow decomposition pathway (Frouz et al., 2013); succession is moving from an early stage as it changes from a bacterial pathway to a fungal pathway (Wardle et al., 1995). The bacterial pathway also shows two things: the litter in the soil is dominated by a matter of $\mathrm{C}: \mathrm{N}$ ratio below 30:1; fast decomposition pathway; and shows that the food web is still at an early stage of succession (Frouz et al., 2013).

Berkelmans et al. (2003) used SI and BI to examine the impact of the agroecosystem on nematode communities. In this study (Figure 2), Agr3 has an excellent soil food web condition with SI $96.36 \%$ and BI $3.54 \%$. Agr2 has a good food web condition with SI $84.62 \%$ and BI $13.17 \%$. Agr1 has moderate soil food web conditions with SI $70.95 \%$ and BI $26.69 \%$. Agr3 has the most complex and undisturbed food web conditions shown in its high SI score. The presence of families of nematodes with various tropic levels influenced this score: bacterivore Cephalobidae, fungivore Aphelenchidae, carnivore Mononchidae, and omnivore Aporcelaimidae. From the BI score, this study shows that Agr3 has the best and undisturbed food web, followed by Agr2, and Agr1. BI is influenced by the abundance of c-p2 nematodes in the community and is most abundant in Agr1 (Cephalobidae).
The enrichment index (EI) is an indicator of resource availability on the food web. Enrichment conditions in the soil food web can occur due to additional external resources, disturbance, environmental shifts, and the death of organisms (Odum, 1985). H. Ferris and Bongers (2006) also concluded that the addition of any suitable material as a substrate for bacteria and soil fungi would trigger an increase in the number of c-p1 nematodes and some c-p2 nematodes. Agr2 has the highest resources (EI 52.24) and is classified as enriched soil $(\mathrm{EI}>50)$ (H. Ferris et al., 2001) while Agr3 (42.86) and Agr1 (23.32) have moderate resources $(\mathrm{EI}<50)$. The abandoned agricultural land can substantially increase soil $\mathrm{C}$ and $\mathrm{N}$ storage (Compton \& Boone 2000), due to an increase in plant diversity (Lange et al., 2015). Resources on Agr2 and Agr3 come from the litter of various growing plants (grass, shrubs, and banana leaves). Meanwhile, in Agr1 the resources only depend on manure because there are only banana plants.

Analysis of the fauna profile (Figure 3) shows that Agr1 and Agr3 belong to the $\mathrm{C}$ quadrant and Agr2 belongs to the $\mathrm{B}$ quadrant. Based on H. Ferris et al. (2001) for the interpretation of fauna profiles, quadrant $\mathrm{C}$ is a food web with the following criteria: undisturbed food web, moderate enrichment, fungal decomposition pathways, moderate to high $\mathrm{C}: \mathrm{N}$ ratio content, and structured. Quadrant B has the following criteria: low disturbance, obtaining $\mathrm{N}$ enrichment, balanced decomposition pathway, low content of $\mathrm{C}: \mathrm{N}$ ratio, and maturity. 
100

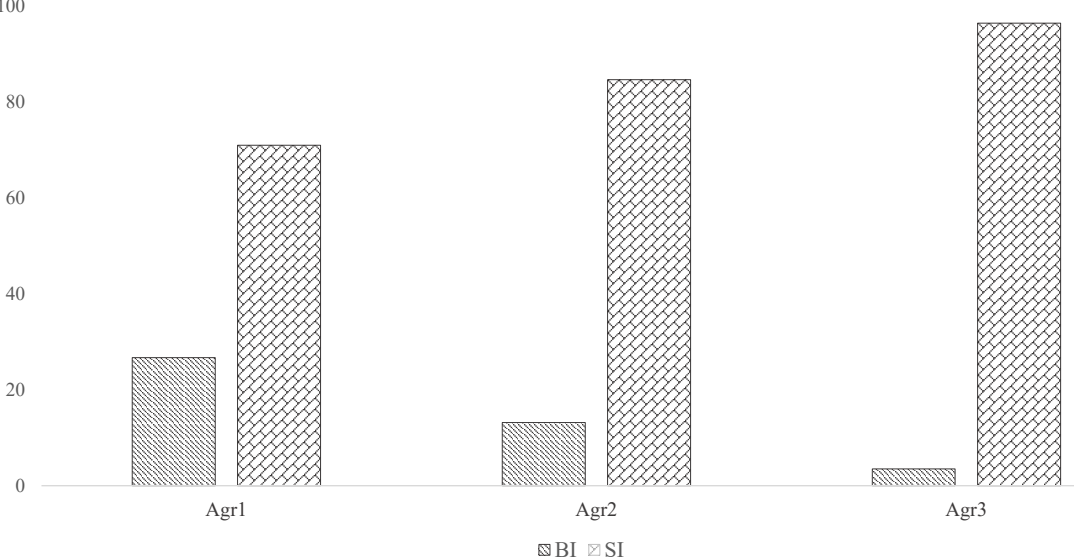

Figure 2. Comparison of SI and BI from all locations

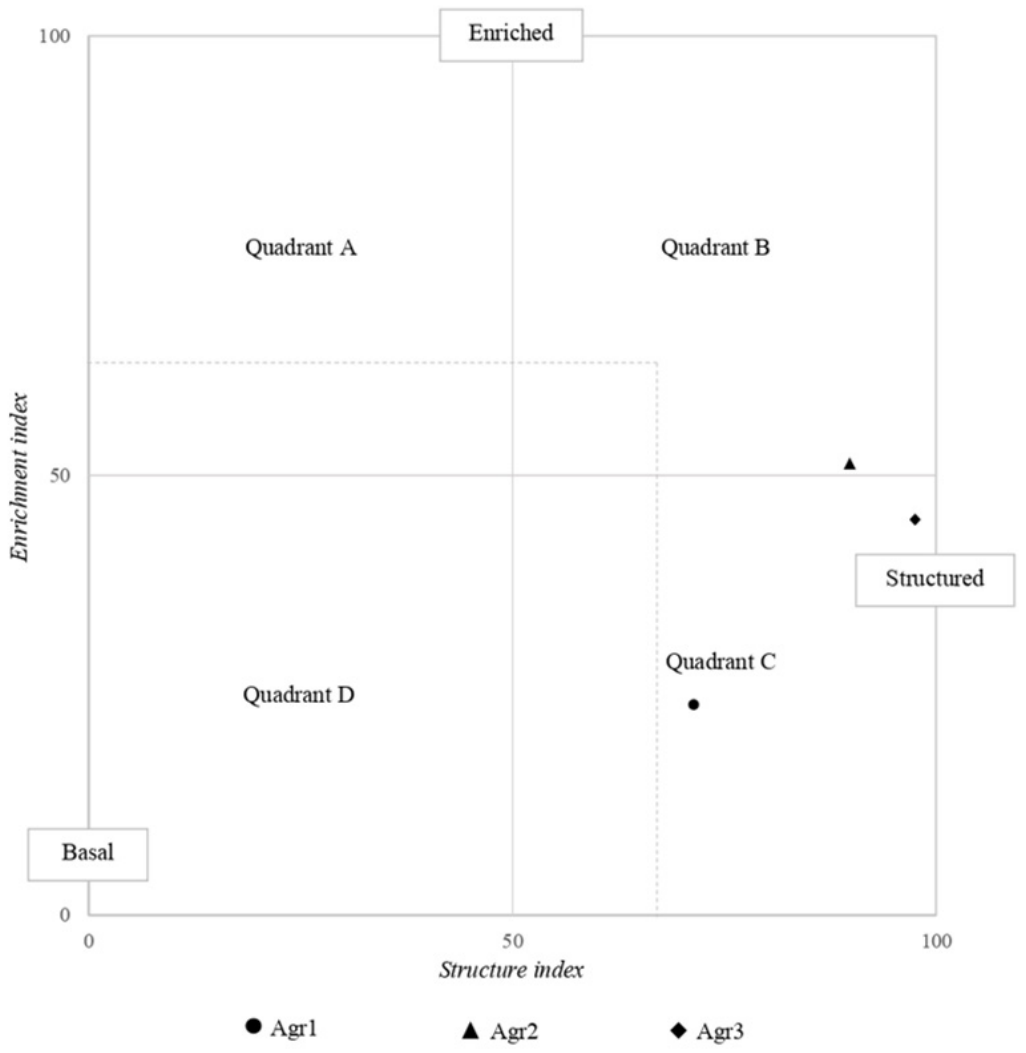

Figure 3. The fauna profile analysis showed that Agr1 and Agr3 belong to the $\mathrm{C}$ quadrant and Agr2 to the $\mathrm{B}$ quadrant 


\section{CONCLUSION}

In this work, the agricultural practices applied to the soil form nematode communities. Tillage and manure increase the group of opportunists and decrease the group of omnivores and carnivores. Soil moisture influences the abundance of bacteria and fungivores. Agr3 has a very complex interaction between trophic, the lowest disturbance level, and structured level succession. Agr2 has complex trophic interactions, low disturbance level, and a mature level succession. Agr1 has moderate interactions between trophic, the highest disturbance level among other locations, and a moderate level succession.

\section{ACKNOWLEDGEMENTS}

The authors would like to thank the local community and banana farmers in Mekargalih, Cianjur, and West Java Indonesia for helping to complete this research. The authors also acknowledge Prof. Dr. Eng. I Made Joni, M.Sc (Department of Physics, Faculty of Mathematics and Natural Sciences, Universitas Padjadjaran) who has helped in completing the writing of this manuscript.

\section{REFERENCES}

Ahmad, R. Z., \& Tiffarent, R. (2020). Pathological aspects of haemonchosis in goats and sheeps. Wartazoa, 30(2), 91-102. https://doi. org/10.14334/wartazoa.v30i2.2185

Andrássy, I. (1983). A taxonomic review of the suborder Rhabditina (Nematoda: Secernentia). ORSTOM.
Baihaqi, Z. A., Widiyono, I., \& Nurcahyo, W. (2019). Prevalence of gastrointestinal worms in Wonosobo and thin-tailed sheep on the slope of Mount Sumbing, Central Java, Indonesia. Veterinary World, 12(11), 1866-1871. https://doi. org/10.14202/vetworld.2019.1866-1871

Barros, P. A., Pedrosa, E. M. R., d Oliveira Cardoso, M. S., \& Rolim, M. M. (2017). Relationship between soil organic matter and nematodes in sugarcane fields. Semina: Ciências Agrárias, 38(2), 551-559. https://doi.org/10.5433/1679$0359.2017 \mathrm{v} 38 \mathrm{n} 2 \mathrm{p} 551$

Berkelmans, R., Ferris, H., Tenuta, M., \& Van Bruggen., A. H. C. (2003). Effects of longterm crop management on nematode trophic levels other than plant feeders disappear after 1 year of disruptive soil management. Applied Soil Ecology, 23(3), 223-235. https://doi. org/10.1016/s0929-1393(03)00047-7

Bongers, T. (1990). The maturity index: An ecological measure of environmental disturbance based on nematode species composition. Oecologia, 83(1), 14-19. https://doi.org/10.1007/BF00324627

Bongers, T., \& Bongers, M. (1998). Functional diversity of nematodes. Applied Soil Ecology, 10(3), 239-251. https://doi.org/10.1016/s09291393(98)00123-1

Bongers, T., \& Ferris, H. (1999). Nematode community structure as a bioindicator in environmental monitoring. Tree, 14(6), 224-228. https://doi. org/10.1016/S0169-5347(98)01583-3

Bongers, T., \& Korthals, G. (1995). The behavior of MI and PPI under enriched conditions. Nematologica, 41, 286.

Bongers, T., Alkemade, R., \& Yeates, G. W. (1991). Interpretation of disturbance-inducedmaturity decrease in marine nematode assemblages by means of the maturity index. Marine Ecology Progress Series, 76, 135-142. 
Briar, S. S., Barker, C., Tenuta, M., \& Entz, M. H. (2012). Soil nematode responses to crop management and conversion to native grasses. Journal of Nematology, 44(3), 245-254.

Brussaard, L., Kuyper, T. W., Didden, W. A. M., De Goede, R. G. M., \& Bloem, J. (2004). Biological soil quality from biomass to biodiversity Importance and resilience to management stress and disturbance. In P. Schjønning, S. Elmholt, \& B. T. Christensen (Eds.), Managing soil quality: Challenges in modern agriculture (pp. 139-161). CABI Publishing.

Budiman, A., Supramana, \& Giyanto. (2020). Phytonematodes associated with arabica coffee in Bondowoso, East Java. IOP Conference Series: Earth and Environmental Science, 418, 012018. https://doi.org/10.1088/1755$1315 / 418 / 1 / 012018$

Celleti, M., \& Potter, J. (2016). Sampling soil and roots for plant parasitic nematodes. http://www.omafra.gov.on.ca/english/crops/ facts/06-099.htm\#: :text=Collect $\% 20$ soil $\% 20$ cores $\% 20$ in $\% 20$ a,or $\% 20$ analyzed $\% 20$ for $\% 20$ nematode $\% 20$ populations

Cesarz, S., Ruess, L., Jacob, M., Jacob, A., Schaefer, M., \& Scheu, S. (2013). Tree species diversity versus tree species identity: Driving forces in structuring forest food webs as indicated by soil nematodes. Soil Biology and Biochemistry, 62, 36-45. https://doi.org/10.1016/j. soilbio.2013.02.020

Compton, J. E., \& Boone, R. D. (2000). Long-term impacts of agriculture on soil carbon and nitrogen in New England forests. Ecology, 81(8), 2314-2330. https://doi.org/10.1890/00129658(2000)081[2314:1tioao]2.0.co;2

Coyne, D. L., Nicol, J. M., \& Claudius-Cole, B. (2014). Practical plant nematology: A field and laboratory guide (2nd ed.). International Institute of Tropical Agriculture.
Daly, A., Baetens, J., \& De Baets, B. (2018). Ecological diversity: Measuring the unmeasurable. Mathematics, 6(7), 119-147. https://doi.org/10.3390/math6070119

De Vries, F. T., Thebault, E., Liiri, M., Birkhofer, K., Tsiafouli, M. A., Bjornlund, L., Jørgensen, H. B., Brady, M. V., Christensen, S., de Ruiter, P. C., d'Hertefeldt, T., Frouz, J., Hedlund, K., Hemerik, L., Gera Hol, W. H., Hotes, S., Mortimer, S. R., Setälä, H., Sgardelis, S. P. ... Bardgett, R. D. (2013). Soil food web properties explain ecosystem services across European land use systems. Proceedings of the National Academy of Sciences, 110(35), 14296-14301. https://doi. org/10.1073/pnas.1305198110

Djiwanti, R. S. (2019). Taxa status of some reported plant-parasitic nematodes in Indonesia. IOP Conference Series: Earth and Environmental Science, 250, 012100. https://doi. org/10.1088/1755-1315/250/1/012100

Ettema, C. H., \& Bongers, T. (1993). Characterization of nematode colonization and succession in disturbed soil using the maturity index. Biology and Fertility of Soils, 16(2), 79-85. https://doi. org/10.1007/bf00369407

Ferris, H., \& Bongers, T. (2006). Nematode indicators of organic enrichment. Journal of Nematology, $38(1), 1-12$.

Ferris, H., Bongers, T., \& De Goede, R. G. M. (2001). A framework for soil food web diagnostics: Extension of the nematode faunal analysis concept. Applied Soil Ecology, 18(1), 13-29. https://doi.org/10.1016/S0929-1393(01)00152-4

Ferris, V. R., \& Ferris, J. M. (1974). Inter-relationships between nematode and plant communities in agricultural ecosystems. Agro-Ecosystems, 1, 275-299. https://doi.org/10.1016/03043746(74)90039-0

Foissner, W. (1997). Protozoa as bioindicators in agroecosystems, with emphasis on 
farming practices, biocides, and biodiversity. Agriculture, Ecosystems and Environment, 62(2-3), 93-103. https://doi.org/10.1016/s01678809(96)01142-5

Freckman, D. W., \& Caswell, E. P. (1985). The ecology of nematodes in agroecosystems. Annual Review of Phytopathology, 23, 275-296. https:// doi.org/10.1146/annurev.py.23.090185.001423

Frouz, J., Thébault, E., Pižl, V., Adl, S., Cajthaml, T., Baldrián, P., Háněl, L., Starý, J., Tajovský, K., Materna, J., Nováková, A., \& de Ruiter, P. C. (2013). Soil food web changes during spontaneous succession at post mining sites: A possible ecosystem engineering effect on food web organization? PLOS One, 8(11), e379694. https://doi.org/10.1371/journal. pone.0079694

Guajardo, S. A. (2015). Measuring diversity in police agencies. Journal of Ethnicity in Criminal Justice, 13(1), 1-15. https://doi.org/10.1080/15 377938.2014.893220

Handayani, N. D., Esquibet, M., Montarry, J., Lestari, P., Couvreur, M., Dikin, A., Helder, J., Grenier, E., \& Bert, W. (2020). Distribution, DNA barcoding and genetic diversity of potato cyst nematodes in Indonesia. European Journal of Plant Pathology, 158(2), 363-380. https://doi. org/10.1007/s10658-020-02078-7

Hooper, D. J., Hallmann, J., \& Subbotin, S. A. (2005). Methods for extraction, processing, and detection of plant and soil nematodes. In M. Luc, R. A. Sikora, \& J. Bridge (Eds.), Plantparasitic nematodes in subtropical and tropical agriculture (pp. 53-86). CABI Publishing.

Jairajpuri, M. S., \& Ahmad, W. (1992). Dorylaimida: Free-living, predaceous and plant-parasitic nematodes. Brill Publisher.

Jost, L. (2010). The relation between evenness and diversity. Diversity, 2(2), 207-232. https://doi. org/10.3390/d2020207
Khoirani, K., Lukman, H. Y., Nikmaturrayan, \& Hosin. (2020). Identification of worm types that infest Bali cattle in Bolo district. Jurnal Riset Veteriner Indonesia, 4(2), 62-68. https://doi. org/10.20956/jrvi.v4i2.9704

Kibblewhite, M., Ritz, K., \& Swift, M. (2008). Soil health in agricultural systems. Philosophical Transactions of the Royal Society B: Biological Sciences, 363(1492), 685-701. https://doi. org/10.1098/rstb.2007.2178

Kim, E., Seo, Y., Kim, Y. S., Park, Y., \& Kim, Y. H. (2017). Effects of soil textures on infectivity of root-knot nematodes on carrot. The Plant Pathology Journal, 33(1), 66-74. https://doi. org/10.5423/PPJ.OA.07.2016.0155

Korthals, G. W., De Goede, R. G. M., Kammenga, J. E., \& Bongers, T. (1996). The maturity index as an instrument for risk assessment of soil pollution. In N. M. van Straalen, \& D. A. Krivolutsky (Eds.), Bioindicator systems for soil pollution (pp. 85-93). Academic Publishers.

Krashevska, V., Kudrin, A. A., Widyastuti, R., \& Scheu, S. (2019). Changes in nematode communities and functional diversity with the conversion of rainforest into rubber and oil palm plantations. Frontiers in Ecology and Evolution, 7(487), 1-10. .https://doi.org/10.3389/ fevo.2019.00487

Kurniawati, F., Nursipa, N. T., \& Munif, A. (2020). Root-knot nematodes in celery (Apium graveolens L.) and its in vitro control using endophytic bacteria. Jurnal Agroekoteknologi, 13(1), 70-81. https://doi.org/10.21107/agrovigor. v13i1.6304

Lange, M., Eisenhauer, N., Sierra, C. A., Bessler, H., Engels, C., Griffiths, R. I., Mellado-Vázquez, P. G., Malik, A. A., Roy, J., Scheu, S., Steinbeiss, S., Thomson, B. C., Trumbore, S. E., \& Gleixner, G. (2015). Plant diversity increases soil microbial activity and soil carbon storage. Nature Communications, 6(1), 6707. https://doi. org/10.1038/ncomms 7707 
Lenz, R., \& Eisenbeis, G. (2000). Short-term effects of different tillage in a sustainable farming system on nematode community structure. Biology and Fertility of Soils, 31(3-4), 237-244. https://doi. org/10.1007/s003740050651

Lisnawita, Supramana, \& Suastika, G. (2012). Identification of potato cyst nematode in Indonesia by polymerase chain reaction. Australasian Plant Disease Notes, 7(1), 133135. https://doi.org/10.1007/s13314-012-0067-5

Liu, T., Chen, X., Hu, F., Ran, W., Shen, Q., Li, H., \& Whalen, J. K. (2016). Carbon-rich organic fertilizers to increase soil biodiversity: Evidence from a meta-analysis of nematode communities. Agriculture, Ecosystems and Environment, 232, 199-207. https://doi.org/10.1016/j. agee.2016.07.015

Liu, X., Zhang, D., Li, H., Qi, X., Gao, Y., Zhang, Y., Han, Y., Jiang, Y., \& Li, H. (2020). Soil nematode community and crop productivity in response to 5-year biochar and manure addition to yellow cinnamon soil. BMC Ecology, 20(1), 39. https:// doi.org/10.1186/s12898-020-00304-8

Masse, D., Pate, E., Ndiaye-Faye, N., \& Cadet, P. (2002). Effect of fallow improvement on the nematode community in the Sudanian region of Senegal. European Journal of Soil Biology, 38(2), 205-211. https://doi.org/10.1016/s11645563(02)01149-4

McSorley, R. (2003). Adaptations of nematodes to environmental extremes. Florida Entomologist, 86(2), 138-142. https://doi.org/10.1653/00154040(2003)086[0138:aontee]2.0.co;2

Mirsam, H., Muis, A., \& Nonci, N. (2020). The density and diversity of plant-parasitic nematodes associated with maize rhizosphere in Malakaji Highland, South Sulawesi, Indonesia. Biodiversitas, 21(6), 2654-2661. https://doi. org/10.13057/biodiv/d210637

Moreno, M., Semprucci, F., Vezzulli, L., Balsamo, M., Fabiano, M., \& Albertelli, G. (2011). The use of nematodes in assessing ecological quality status in the Mediterranean coastal ecosystems. Ecological Indicators, 11(2), 328-336. https:// doi.org/10.1016/j.ecolind.2010.05.011

Mutala'liah, Indarti, S., \& Putra, N. S. (2018). Short communication: Abundance and diversity of plant-parasitic nematodes associated with BP 308 and BP 42 clones of robusta coffee in Java, Indonesia. Biodiversitas, 19(1), 67-70. https:// doi.org/10.13057/biodiv/d190111

Neher, D. A. (1999). Soil community composition and ecosystem processes: Comparing agricultural ecosystems with natural ecosystems. Agroforestry Systems, 45(1), 159-185. https:// doi.org/10.1023/a:1006299100678

Neher, D. A., \& Campbell, C. L. (1994). Nematode communities and microbial biomass in soils with annual and perennial crops. Applied Soil Ecology, 1(1), 17-28. https://doi.org/10.1016/09291393(94)90020-5

Neher, D. A., Peck, S. L., Rawlings, J. O., \& Campbell, C. L. (1995). Measures of nematode community structure and sources of variability among and within agricultural fields. Plant and Soil, 170(1), 167-181. https://doi.org/10.1007/ bf02183065

Nguyen, K. B. (2006). Suborder Rhabditina. http:// entnemdept.ufl.edu/nguyen/morph/rhabdi/ rhabkey.HTM

Nguyen, K. B. (2009). Illustrated key for the identification of nematodes in the suborder of Cephalobina. http://entnemdept.ufl.edu/nguyen/ morph/cephalob/cephakey.htm

Nielsen, U. N., Ayres, E., Wall, D. H., Li, G., Bardgett, R. D., Wu, T., \& Garey, J. R. (2014). Globalscale patterns of assemblage structure of soil nematodes in relation to climate and ecosystem properties. Global Ecology and Biogeography, 23(9), 968-978. https://doi. org/10.1111/geb.12177 
Odum, E. P. (1985). Trends expected in stressed ecosystems. BioScience, 35(7), 419-422. https:// doi.org/10.2307/1310021

Okada, H., \& Harada, H. (2007). Effects of tillage and fertilizer on nematode communities in a Japanese soybean field. Applied Soil Ecology, 35(3), 582598. https://doi.org/10.1016/j.apsoil.2006.09.008

Ortiz, V., Phelan, S., \& Mullins, E. (2016). A temporal assessment of nematode community structure and diversity in the rhizosphere of cisgenic Phytophthora infestans-resistant potatoes. BMC Ecology, 16(1), 55. https://doi.org/10.1186/ s12898-016-0109-5

Peña-Santiago, R. (2006). Dorylaimida part I: Superfamilies Belondoridea, Nygolaimoidea and Tylencholaimoidea. In Eyualem-Abebe, I. Andrassy, \& W. Traunspurger (Eds.), Freshwater nematodes ecology and taxonomy (pp. 326-391). CABI Publishing.

Peña-Santiago, R. (2014a). Order Dorylaimida Pearse, 1942. In A. Schmidt-Rhaesa (Ed.), Handbook of zoologi Gastrotricha, Cycloneuralia and Gnathifera: Nematoda (pp. 277-298). Walter de Gruyter.

Peña-Santiago, R. (2014b). Order Mononchida Jairajpuri, 1969. In A. Schmidt-Rhaesa (Ed.), Handbook of zoologi Gastrotricha, Cycloneuralia and Gnathifera: Nematoda (pp. 299-312). Walter de Gruyter.

Pielou, E. C. (1969). An introduction to mathematical ecology. Wiley.

Ponge, J.-F., Pérès, G., Guernion, M., Ruiz-Camacho, N., Cortet, J., Pernin, C., Villenave, C., Chaussod, R., Martin-Laurent, F., Bispo, A., \& Cluzeau, D. (2013). The impact of agricultural practices on soil biota: A regional study. Soil Biology and Biochemistry, 67, 271-284. https://doi. org/10.1016/j.soilbio.2013.08.026

Quénéhervé, P., Barrière, V., Salmon, F., Houdin, F., Achard, R., Gertrude, J.-C., Marie-Luce,
S., Chabrier, C., Duyck, P-F., \& Tixier, P. (2011). Effect of banana crop mixtures on the plant-feeding nematode community. Applied Soil Ecology, 49, 40-45. https://doi.org/10.1016/j. apsoil.2011.07.003

Renčo, M., Gömöryová, E., \& Čerevková, A. (2020). The effect of soil type and ecosystems on the soil nematode and microbial communities. Helminthologia, 57(2), 129-144. https://doi. org/10.2478/helm-2020-0014

Sakaguchi, S., Yunus, M., Sugi, S., \& Sato, H. (2019). Integrated taxonomic approaches to seven species of capillariid nematodes (Nematoda: Trichocephalida: Trichinelloidea) in poultry from Japan and Indonesia, with special reference to their $18 \mathrm{~S}$ rDNA phylogenetic relationships. Parasitology Research, 119, 957-972. https://doi.org/10.1007/s00436-01906544-y

Scholze, V. S., \& Sudhaus, W. (2011). A pictorial key to current genus groups of 'Rhabditidae'. Journal of Nematode Morphology and Systematics, 14(2), 105-112.

Sholeha, A. R., Maharning, A. R., \& Nasution, E. K. (2017). Nematode community response to varied proportion of decomposing plant litter. Scripta Biologica, 4(3), 161-164. https://doi. org/10.20884/1.SB.2017.4.3.588

Siddiqi, M. R. (Ed.) (2000). Tylenchida: Parasites of plants and insects. CABI Publishing. http://doi. org/10.1079/9780851992020.0000

Simpson, E. H. (1949). Measurement of diversity. Nature, 163(4148), 688. https://doi. org/10.1038/163688a0

Statistics Indonesia. (2019). Statistik tanaman buahbuahan dan sayuran tahunan Indonesia 2018 [Indonesia annual fruit and vegetable crop statistics for 2018]. https://www.bps.go.id/pub lication/2019/10/07/1846605363955649c9f6dd 6d/statistik-tanaman-buah-buahan-dan-sayurantahunan-indonesia-2018.html 
Subbotin, S. A. (2014). Order Tylenchida Thorne, 1949. In A. Schmidt-Rhaesa (Ed.), Handbook of zoologi Gastrotricha, Cycloneuralia and Gnathifera: Nematoda (pp. 613-636). Walter de Gruyter.

Treonis, A. M., Sutton, K. A., Unangst, S. K., Wren, J. E., Dragan, E. S., \& McQueen, J. P. (2019). Soil organic matter determines the distribution and abundance of nematodes on alluvial fans in Death Valley, California. Ecosphere, 10(4), e02659. https://doi.org/10.1002/ecs2.2659

Van Bezooijen, J. (2006). Methods and techniques for nematology. Wageningen University.

Varga, I., Benković-Lačić, T., Lončarić, Z., Popović B, \& Brmež, M. (2019). Liming, phosphorus and zinc influence on soil nematode community structure at hot pepper. Horticultural Science, 46(2), 65-71. https://doi.org/10.17221/217/2017hortsci

Vinciguerra, M. T. (2006). Dorylaimida part II: Superfamily Dorylaimoidea. In EyualemAbebe, I. Andrassy, \& W. Traunspurger (Eds.), Freshwater nematodes ecology and taxonomy (pp. 392-467). CABI Publishing.

Wang, K, H., McSorley, R., \& Gallaher, R. N. (2004). Relationship of soil management history and nutrient status to nematode community structure. Nematropica, 34(1), 83-95.

Wardle, D. A., Yeates, G. W., Watson, R. N., \& Nicholson, K. S. (1995). Development of the decomposer food-web, trophic relationships, and ecosystem properties during a three-year primary succession in Sawdust. Oikos, 73(2), 155. https:// doi.org/10.2307/3545904
Wasilewska, L. (1989). Impact of human activities on nematode communities in terrestrial ecosystems. In M. Clarholm \& L. Bergström (Eds.), Ecology of Arable land - Perspectives and challenges. Developments in plant and soil sciences (Vol. 39, pp. 123-132). Springer. https://doi. org/10.1007/978-94-009-1021-8_12

Yardim, E. N., \& Edwards, C. A. (1998). The effects of chemical pest, disease and weed management practices on the trophic structure of nematode populations in tomato agroecosystems. Applied Soil Ecology, 7(2), 137-147. https://doi. org/10.1016/s0929-1393(97)00036-x

Yeates, G. W., Bongers, T., De Goede, R. G. M., Freckman, D. W., \& Georgieva, S. S. (1993). Feeding habits in soil nematode families and genera - An outline for soil ecologists. Journal of Nematology, 25(3), 315-331.

Zhong, S., Zeng, H., \& Jin, Z. (2015). Responses of soil nematode abundance and diversity to long-term crop rotations in Tropical China. Pedosphere, 25(6), 844-852. https://doi.org/10.1016/s10020160(15)30065-5

Zulini, A., \& Peneva, V. (2006). Order Mononchida. In Eyualem-Abebe, I. Andrassy, \& W. Traunspurger (Eds.), Freshwater nematodes ecology and taxonomy (pp. 468-496). CABI Publishing. 
